Research Article

\title{
Serum Uric Acid: A Novel Risk Factor for Gestational Diabetes Mellitus
}

\author{
Singh $\mathrm{U}^{1}$, Mehrotra $\mathrm{S}^{2}$, Singh $\mathrm{R}^{3}$, Sujata ${ }^{4}$, Gangwar $\mathrm{ML}^{5}$, Shukla $\mathrm{B}^{6}$ \\ ${ }^{1}$ Dr Urmila Singh, Professor, ${ }^{2}$ Dr Seema Mehrotra, Associate Professor, ${ }^{3}$ Dr Renu Singh, Associate Professor ${ }^{4}$ Dr Sujata, \\ Associate Professor, ${ }^{5}$ Dr. Madhu Lata Gangwar, Ex-Resident, ${ }^{6}$ Dr. Bhumika Shukla, Resident. All are affiliated with \\ Department of Obstetrics and Gynaecology, King George Medical University, Lucknow, UP, India.
}

Corresponding Author: Dr Seema Mehrotra, Email: mehrotra.seema@gmail.com

\begin{abstract}
Introduction: To analyze the relationship between first trimester uric acid levels and risk of development of gestational diabetes mellitus (GDM). Method: A total of 300 pregnant women up to 14 weeks of pregnancy were enrolled in this study. After obtaining their demographic data and clinical assessment blood sample for serum uric acid was taken. Women were subsequently followed till term. All women were subjected to blood sugar screening one hour after $50 \mathrm{gm}$ glucose and glucose tolerance test if screening was $<200 \mathrm{mg} / \mathrm{dl}$. GDM was diagnosed by 3 hours glucose tolerance test using Carpenter and Coustan criteria or by one hour screening value $>200 \mathrm{mg} / \mathrm{dl}$. Results: GDM complicated 2.66\% $(8 / 300)$ of the pregnancies. All the women with serum uric acid $>5 \mathrm{mg} / \mathrm{dl}(\mathrm{n}=6)$ had deranged blood sugar screening and out of this 5 developed GDM. Conclusion: The study demonstrates a striking association between first trimester uric acid and risk of developing GDM. First trimester uric acid level may be used as predictor for development of GDM.
\end{abstract}

Keywords: Uric Acid, Gestational Diabetes Mellitus, Insulin Resistance, Glucose Tolerance Test

\section{Introduction}

Approximately $7 \%$ of all pregnancies are complicated by gestational diabetes mellitus (GDM), resulting in more than 2, 00,000 cases annually. The prevalence may range from $1-14 \%$ of all pregnancies depending on the population studied and the diagnostic test employed [1].

It is well recognized that GDM and also milder degree of carbohydrate intolerance are associated with increased perinatal complications and adverse pregnancy outcomes [2]. Several studies have now shown that, compared to their peers, women who go on to develop GDM later in pregnancy have biochemical abnormalities that can be detected in the first trimester including increased levels of uric acid $[3,4]$.

Uric acid, the final oxidation product of purine metabolism, is associated with insulin resistance [5- 7]. Accumulating evidence from different studies suggests that uric acid could also play a role in glucose homeostasis by increasing insulin resistance, by inhibiting insulin mediated endothelial nitric oxide release and by directly acting on adipocyte [8-12].

Manuscript received: $4^{\text {th }}$ Nov 2013

Reviewed: $16^{\text {th }}$ Nov Aug

Author Corrected; $19^{\text {th }}$ Nov 2013

Accepted for Publication: $28^{\text {th }}$ Nov 2014
A large body of evidence supports the fact that uric acid could be an important risk factor for development of Type 2 Diabetes, especially in women [13-15]. Hyperuricaemia is also associated with markers of metabolic syndrome [16-20]. Interesting relationships have been observed between serum uric acid, serum glucose and diabetes, but the studies have not been consistent [21,22].

Studies have shown that normally in pregnancy, serum uric acid level falls in early and middle pregnancy and rises to preconception values in late pregnancy. Compared with pre pregnancy values, uric acid concentration decreased significantly by 8 weeks gestation and this reduced level was maintained until about 24 weeks. Thereafter the concentrations increased such that by term they were greater than the prepregnancy values in the majority of patients and remained elevated until at least 12 weeks after delivery [23]. Thus elevated serum uric acid in early pregnancy may identify women who are at an increased risk of developing gestational diabetes mellitus.

It is possible that, of the women who develop gestational diabetes mellitus, those with elevated first 
Research Article

trimester uric acid concentration are the women who are at an increased risk of developing Type 2 Diabetes Mellitus and this warrant future investigations and management of patients. So we intended this study to assess the relationship between maternal serum uric acid concentration in early pregnancy and development of gestational diabetes mellitus (GDM).

\section{Material and Methods}

The study was approved by medical ethics committee of the institution. All participants were given adequate information and consent was obtained from each participant. Pregnant women upto 14 weeks of gestation were enrolled in this prospective cohort study. Women who were known cases of diabetes mellitus, chronic hypertension, gout, renal disease, connective tissue disorder or had history of thromboembolism were excluded from the study. 310 eligible women were enrolled, out of which 10 were lost to follow up and hence a cohort of 300 women remained for analysis.

All enrolled women were subjected to detailed history and clinical examination. All routine antenatal investigations along with serum uric acid concentration were carried out. $2 \mathrm{ml}$ of blood sample was drawn from the antecubital vein following 12 hours fasting from all women upto 14 weeks of gestation. The blood sample was centrifuged to separate the serum and was stored at $-70^{\circ} \mathrm{C}$ until analysis. Uric acid was measured by using a colorimetric assay kit U 7581-120; Pointe scientific Inc., Canton, MI with a detection limit of $10 \mathrm{mg} / \mathrm{dl}$.

All the subjects were followed up till term. GDM was diagnosed by two step approach as per the departmental protocol. Blood sugar screening 1 hour after $50 \mathrm{gm}$ oral glucose irrespective of meal was measured in all registered women between 24-26 weeks of gestational age. Women with blood sugar screening $>140 \mathrm{mg} / \mathrm{dl}$ were labeled as having deranged blood sugar screening.

Women with blood sugar screening $\geq 200 \mathrm{mg} / \mathrm{dl}$ were directly labeled as having GDM and all the others (with normal and deranged blood sugar screening) further underwent oral glucose tolerance test with $100 \mathrm{gm}$ glucose. GDM was diagnosed if 2 or more plasma glucose levels meet or exceed the thresholds given by Carpenter and Coustan criteri [24].

Using structured questionnaires, information was collected on other covariates like maternal sociodemographic, behavioral and medical characteristic. Covariate information included maternal age, prepregnancy weight, height, reproductive and personal and family medical history. Prepregnancy body mass index (BMI) used as an index of maternal adiposity was calculated as weight $(\mathrm{kg})$ divided by height $(\mathrm{m})$ squared. The statistical analysis was done using Stata, version 11.2 statistical analysis software.

\section{Results}

A total of 300 women were analyzed with mean age $24.85 \pm 3.39$ years and the mean BMI 22.79 \pm 2.50 (Table 1). GDM complicated $8(2.66 \%)$ of the pregnancies. None of the women having GDM were found to be obese $\left(\mathrm{BMI} \geq 30 \mathrm{~kg} / \mathrm{m}^{2}\right)$ in our study. Out of this 5 women $(5 / 8,62.5 \%)$ had early pregnancy mean uric acid concentration of $5.60 \pm 0.5 \mathrm{mg} / \mathrm{dl}$ and 3 women $(3 / 8,37.5 \%)$ had mean uric acid concentration of $4.33 \pm 0.2 \mathrm{mg} / \mathrm{dl}$.

Table 1: Demographic variables of women enrolled in the study $(n=300)$

\begin{tabular}{|l|c|}
\hline Variables & Mean \pm SD \\
\hline Age (Years) & $24.85 \pm 3.39$ \\
\hline Weight $(\mathrm{kg})$. & $51.31 \pm 6.24$ \\
\hline Height $(\mathrm{cm})$. & $152.35 \pm 2.11$ \\
\hline BMI $\left(\mathrm{kg} / \mathrm{m}^{2}\right)$ & $22.79 \pm 2.50$ \\
\hline
\end{tabular}

On correlating the early pregnancy serum uric acid concentration with blood sugar screening, it was found that blood sugar screening was normal $(<140 \mathrm{mg} / \mathrm{dl})$ in the subjects $(\mathrm{n}=269)$ with serum uric acid concentration $\leq 4 \mathrm{mg} / \mathrm{dl}$. In the subjects $(\mathrm{n}=25)$ with serum uric acid concentration between $4.1-4.9 \mathrm{mg} / \mathrm{dl}$ (mean= $4.33 \pm 0.2 \mathrm{mg} / \mathrm{dl}), 14 \mathrm{had}$ deranged blood sugar screening ( $\geq 140 \mathrm{mg} / \mathrm{dl})$, out of which $3(12 \%)$ had abnormal glucose tolerance test. Subjects ( $\mathrm{n}=6)$ having serum uric acid $>5 \mathrm{mg} / \mathrm{dl}(\mathrm{mean}=5.60 \pm 0.6 \mathrm{mg} / \mathrm{dl})$, all 6 had deranged blood sugar screening $(\geq 140 \mathrm{mg} / \mathrm{dl})$ and out of this, 5 had abnormal glucose tolerance test (Table 2). 
Research Article

Table 2: Association of serum uric acid with blood sugar screening (1 hr after $50 \mathrm{gm}$ glucose) and development of GDM

\begin{tabular}{|l|c|c|c|c|c|c|}
\hline Groups & \multicolumn{2}{|c|}{ Uric acid level (mg/dl) } & \multicolumn{2}{c|}{$\begin{array}{c}\text { Blood Sugar } \\
\text { Screening(mg/d) }\end{array}$} & \multicolumn{2}{c|}{ OGTT } \\
\hline & Range & Mean \pm SD & $<\mathbf{1 4 0}$ & $\mathbf{1 4 0}$ & $\begin{array}{c}\text { Positive } \\
\text { (GDM) }\end{array}$ & $\begin{array}{c}\text { Negative } \\
\text { (Non GDM) }\end{array}$ \\
\hline I(n=155) & $2.0-3.0$ & $2.61 \pm 0.3$ & 155 & 0 & 0 & 155 \\
\hline II(n=114) & $3.1-4.0$ & $3.43 \pm 0.3$ & 114 & 0 & 0 & 114 \\
\hline $\mathbf{I I I}(\mathrm{n}=25)$ & $4.1-4.9$ & $4.33 \pm 0.2$ & 11 & 14 & $3(12 \%)$ & 22 \\
\hline $\mathbf{I V}(\mathrm{n}=6)$ & $\geq 5$ & $5 . .60 \pm 0.6$ & 0 & 6 & $5(83.3 \%)$ & 1 \\
\hline
\end{tabular}

Using a cut off value of serum uric acid $\geq 5 \mathrm{mg} / \mathrm{dl}$, yielded a positive predictive value of $83.33 \%$, negative predictive value of $98.3 \%$, sensitivity of $62.5 \%$ and specificity of $99.7 \%$ at $95 \%$ confidence interval. The area under receiver operator curve was 0.997 which indicates a fair diagnostic efficacy of serum uric acid as a marker for GDM at a cut off value of 5 $\mathrm{mg} / \mathrm{dl}$ (Figure 1).

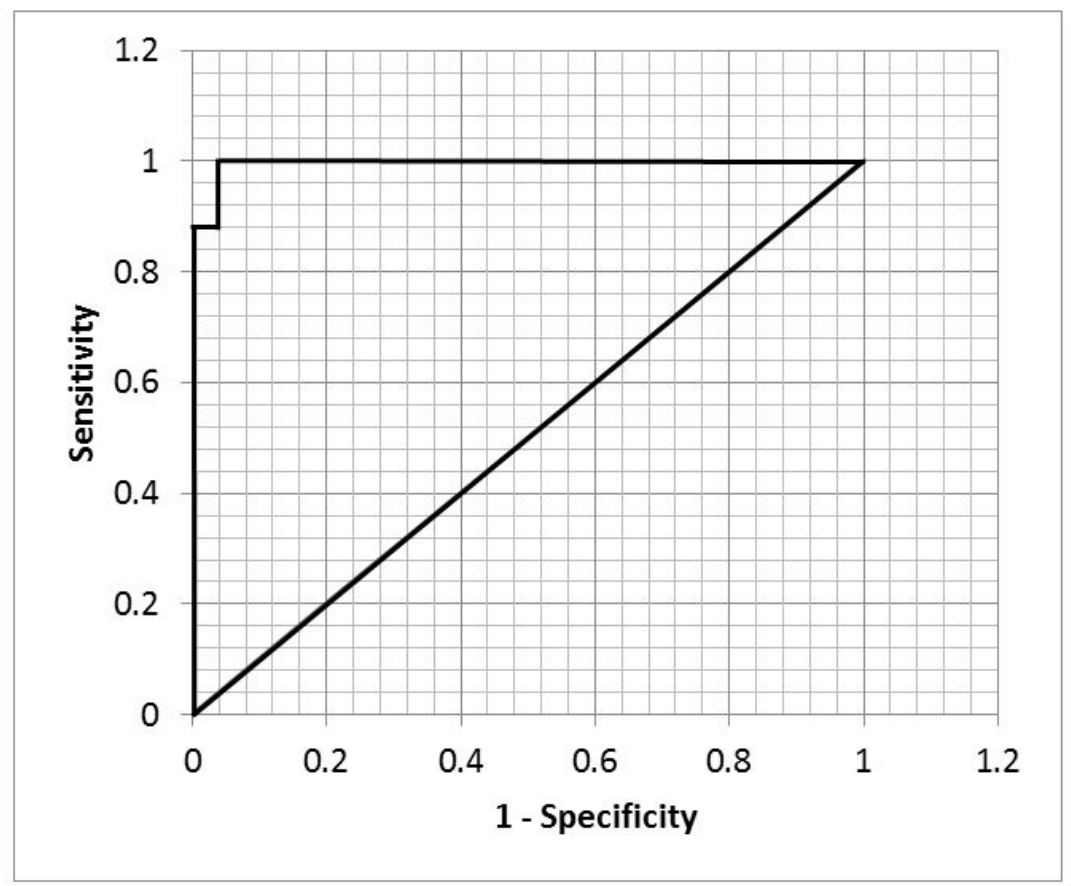

Fig 1: ROC Curve

\section{Discussion}

In this prospective cohort study, we observed a direct relationship between serum uric acid concentration and incidence of GDM. Women with serum uric acid level $\geq$ $5 \mathrm{mg} / \mathrm{dl}$ in early pregnancy (upto 14 wks gestation), had $83.33 \%$ more chance of development of GDM. Statistical analysis indicates a fair diagnostic efficacy of serum uric acid level as a marker for GDM at a cut off value of $5 \mathrm{mg} / \mathrm{dl}$. This association was independent of established sociodemographic risk factors of GDM such as maternal age, prepregnancy BMI and family history of Type 2 diabetes.
Uric acid is the final oxidation product of purine catabolism which kidneys excrete as a waste product [5]. A growing body of evidence from animal and human studies suggests that uric acid can also play part in glucose homeostasis by increasing insulin resistance [6]. Two mechanisms have been hypothesized. The first proposed mechanism is that uric acid causes endothelial dysfunction and decreases endothelial nitric oxide production, thus inhibiting insulin mediated nitric oxide release which accounts for one-third of insulin's action by increasing blood flow to skeletal muscle and 
Research Article

peripheral tissues and enhancing glucose uptake [8-10]. The second proposed mechanism is by a direct effect of uric acid on adipocyte. There is evidence that insulin resistance is mediated in part by inflammation and oxidative stress within the adipocyte [12].

Our findings are consistent with a relatively large body of literature documenting a direct relationship between serum uric acid levels and hyperglycemia, insulin resistance and Type 2 Diabetes. For instance, Laughon et al. [25] reported that women having mean serum uric acid level of $4.2 \mathrm{mg} / \mathrm{dl}$ in early pregnancy (mean gestational age $=8.9 \pm 2.5 \mathrm{wks}$ ) had a three fold increased risk of developing GDM, as compared to those with mean serum uric acid level of $2.1 \mathrm{mg} / \mathrm{dl}$.

Wolak et al [26] performed multivariate analysis and concluded that uric acid levels in the highest quartile ( $>$ $5.5 \mathrm{meq} / \mathrm{l}$ ) of the normal range during first 20 weeks of pregnancy are associated with higher risk of development of GDM. In agreement with our results, Gharib et al [27] demonstrated that first trimester hyperuricemia was associated with an increased risk of developing GDM.

Gharib et al in their study on 250 first trimester pregnant females susceptible to diabetes mellius found serum uric acid $>4 \mathrm{mg} / \mathrm{dl}$, in early pregnancy is associated with increased risk of developing GDM. These results are in accordance with multiple animal and human based studies that demonstrate direct relationship between increased serum uric acid level and insulin resistance [7, $12,13,28]$.

The likelihood of bias, particularly selection bias and recall bias is minimized in this present study because of prospective study design and the high follow up rate. The percentage of women having BMI $\geq 30 \mathrm{~kg} / \mathrm{m}^{2}$ was less than $1 \%$, so adjustment for BMI was not done in the present study.

Nevertheless, several limitations of present study merit discussion. Although, we adjusted for several known and suspected confounders, we cannot exclude the possibility of residual confounding. Moreover, given the relatively small size of the study cohort, estimated effect measures were imprecise as reflected by their relatively wide $95 \%$ confidence intervals.

In summary, findings from this prospective study are generally consistent with previous studies which have shown strong co-relation between serum uric acid and development of GDM.
Taken together, these converging lines of evidence suggest that serum uric acid concentration in early pregnancy is a unique risk marker for development of GDM and these women need long term follow up for the development of type 2 diabetes mellitus.

Funding: Nil

Permission from IRB: Yes

Conflicts of interest: The authors report no conflicts of interest.

\section{References}

1. American Diabetes Association. Gestational diabetes mellitus. Diabetes care. 2003 Jan: 26 Supp11: S103-5.

2. Gollenberg AL ,Pekow P, Bertone-Johnson ER,Freedom PS, Markenson G et al. Sedentary behaviors and abnormal glucose tolerance among pregnant Latina women. Med Sci Sports Exerc. 2010 Jun; 42 (6):1079-85. doi: 10.1249/MSS.0b013e3181 c6dec8.

3. Riskin-Mashiah S, Damti A, Younes G, Auslender R. First trimester fasting hyperglycemia as a predicter for the development of gestational diabetes mellitus. Eur J Obstet Gynecol Reprod Biol. 2010 Oct;152(2):163-7. doi: 10.1016/j.ejogrb.2010.05.036. Epub 2010 Jul 1.

4. Savvidou M, Nelson SM, Makgoba CM,Sattar N,Nicolaides K.First-trimester prediction of gestational diabetes mellitus. Examining the potential of combining maternal characterstics and laboratory measures. Diabetes 2010; 59: 3017-22.

5. Wolfgang Koenig and Christa Meisinger.Uric acid, type 2 diabetes and cardiovascular disease: fueling the common soil hypothesis? Clin Chem. 2008 Feb;54(2): 231-3. doi: 10.1373/clinchem.2007.099705.

6. Modan M, Halkin H, Karasik A, Lusky A. Elevated serum uric acid, a facet for hyperinsulinaemia. Clin Chem. 2008 Feb;54(2):231-3. doi: 10.1373/clinchem. 2007. 099705.

7. Facchini F, Chen YD, Hollenbeck CB, Reaven GM. Relationship between resistance to insulin mediated glucose uptake, urinary uric acid clearance and plasma uric acid concentration. JAMA. 1991 Dec 4;266(21): 3008-11.

8. Roy D, Perreault M, Marette A. Insulin stimulation of glucose uptake in skeletal muscles and adipose tissues in vivo is NO dependent. Am J Physiol. 1998 Apr;274(4 Pt 1):E692-9.

Available online at: $\underline{\text { www.ijmrr.in }} 13$ | P a g e 
Research Article

9. Khosla UM. Hyperuricaemia induces endothelial dysfunction. Kidney Int. 2005 May;67(5):1739-42.

10. Kang DH, Park SK, Lee IK, Johnson RJ. Uric acid induced C-reactive protein expression: implication on cell proliferation and nitric oxide production of human vascular cells. J Am Soc Nephrol. 2005 Dec;16(12): 3553-62. Epub 2005 Oct 26.

11. Butler R, Morris AD, Belch JJ, Hill A, Struthers AD. Allopurinol normalizes endothelial dysfunction in type 2 diabetics with mild hypertension. Hypertension. 2000 Mar;35(3):746-51.

12. Furukawa S, Fujita T, Shimabukuro M. Increased oxidative stress in obesity and its impact on metabolic syndrome. J Clin Invest. 2004 Dec;114(12):1752-61.

13. Dehghan A, Van Hoek M, Sijbrands EJ,Hofman A.,Wilteman JC. High serum uric acid as a novel risk factor for type 2 diabetes. Diabetes Care. 2008 Feb;31(2):361-2. Epub 2007 Oct 31.

14. Kodama S, Saito K, Yachi Y,Asumi M,Sugawara A,Totsuka $\mathrm{K}$ et al. Assocociation between serum uric acid and development of type 2 diabetes. Diabetes Care. 2009 Sep;32(9):1737-42. doi: 10.2337/dc09-0288. Epub 2009 Jun 23.

15. Panero F,Gruden G, Perotto M, Fornengo P,Barutta $\mathrm{F}$,Greco $\mathrm{E}$ et al. Uric acid is not an independent predictor of cardiovascular mortality in type 2 diabetes: A population -based study. Atherosclerosis. 2012 Mar;221(1):183-8. doi: 10.1016/j.atherosclerosis. 2011.11.042. Epub 2011 Dec 26.

16. Nakagawa T, Tuttle KR, Short RA, Johnson RJ. Hypothesis: fructose induced hyperuricaemia as a causal mechanism for the epidemic of the metabolic syndrome. Nat Clin Pract Nephrol. 2005 Dec;1(2):80-6.

17. Masuo K, Kagawaguchi H, Mikami H, Ogihara T, Tuck ML. Serum uric acid and plasma norepinephrine concentrations predict subsequent weight gain and blood pressure elevation. Hypertension. 2003 Oct;42(4):47480. Epub 2003 Sep 2.

18. Ames BN, Cathcart R, Schwiers E, Hochstein P. Uric acid provides an antioxidant defense in humans against oxidant and radical caused aging and cancer: a hypothesis. Proc Natl Acad Sci U S A. 1981 Nov;78(11):6858-62.

19. Choi HK, Ford ES. Prevalence of the metabolic syndrome in individuals with hyperuricaemia. Am J Med. 2007 May;120(5):442-7.

20. Yoo TW, Sung KC,Shin HS, Kim BJ, Kim BS,Kang $\mathrm{JH}$,et al. Relationship between serum uric acid concentration and insulin resistance and metabolic syndrome. Circ J. 2005 Aug;69(8):928-33.

21. Derek G. Cook, A.G.Shaper, D.S.Thelle, T.P.Whitehead. Serum uric acid, serum glucose and diabetes: relationship in a population study. Postgrad Med J. 1986 Nov;62(733):1001-6.

22. Carstensen M, Herder C, Kivimaki M,Jokela M,Roden M, Shipley MJ,et al. Accelerated increase in serum interleukin-1 receptor antagonist starts 6 years before diagnosis of type 2 diabetes: Whitehall II prospective cohort study. Diabetes. 2010 May;59(5):1222-7. doi: 10.2337/db09-1199. Epub 2010 Feb 25

23. Lind T, Godfrey KA, Otun H, Philips PR. Changes in serum uric acid concentrations during normal pregnancy. Br J Obstet Gynaecol. 1984 Feb;91(2):12832.

24. Carpenter MW, Coustan DR. Criteria for screening tests for gestational diabetes. Am J Obstet Gynecol. 1982 Dec 1;144(7):768-73.

25. Katherine Laughon, Janet Catov, Traci Provins, James M Roberts, Robin E.Gandley: Elevated first trimester uric acid concentrations are associated with development of gestational diabetes. Am J Obstet Gynecol. 2009 Oct;201(4):402.e1-5. doi: 10.1016/j .ajog.2009.06.065.

26. Wolak T, Sergienko R, Wiznitzer A, Paran E, Sheiner E. High uric acid level during the first 20 weeks of pregnancy is associated with higher risk for gestational diabetes mellitus and mild preeclampsia.

Hypertens Pregnancy. 2012;31(3):307-15. doi: 10.3109/10641955.2010.507848. Epub 2010 Sep 7. 


\section{Research Article}

27. Gharib MN, Mahfouz AE, Morad M A, Farhat MA. Prediction of gestational diabetes by measuring first trimester maternal serum uric acid concentration. Journal of Basic and Clinical reproductive Sciences. $2013 ; 2: 27-31$
28. Sautin YY, Nakagawa T, Zharikov S, Johnson RJ.Adverse effects of the classic antioxidant uric acid in adipocytes: NADPH oxidase-mediated oxidative/ nitrosative stress. Am J Physiol Cell Physiol. 2007 Aug;293(2):C584-96. Epub 2007 Apr 11.

\section{How to cite this article?}

Singh U, Mehrotra S, Singh R, Sujata, Gangwar ML, Shukla B. Serum Uric Acid: A Novel Risk Factor for Gestational Diabetes Mellitus. Int J Med Res Rev 2015;3(1):10-15. doi:10.17511/ijmrr.2015.i1.03 